\title{
Growth performance and survival rate of striped eel catfish (Plotosus lineatus) in the domestication
}

\author{
ASRIYANA ASRIYANA ${ }^{1, \boldsymbol{v}}$, HALILI HALILI ${ }^{1}$, MUHAIMIN HAMZAH ${ }^{2}$, AGUS KURNIA ${ }^{2}$ \\ ${ }^{1}$ Department of Aquatic Resources Management, Faculty of Fisheries and Marine Sciences, Universitas Halu Oleo. Jl. H.E.A.Mokodompit, Kampus \\ Bumi Tridharma Anduonohu, Kendari 93232, Southeast Sulawesi, Indonesia. Tel./fax.: +62-813-80069446, ^email: asriyana@uho.ac.id \\ ${ }^{2}$ Department of Aquaculture, Faculty of Fisheries and Marine Sciences, Universitas Halu Oleo. J1. H.E.A.Mokodompit, Kampus Bumi Tridharma \\ Anduonohu, Kendari 93232, Southeast Sulawesi, Indonesia
}

Manuscript received: 21 October 2021. Revision accepted: 27 November 2021.

\begin{abstract}
Asriyana, Halili, Hamzah M, Kurnia A. 2021. Growth performance and survival rate of striped eel catfish (Plotosus lineatus) in the domestication. Biodiversitas 22: 5593-5599. The striped eel catfish, Plotosus lineatus, is one of the catfishes that live in coral reefs and have high economic value. The fish is available in the wild and can be domesticated to supply animal protein necessity. This study aims to determine the optimum catfish size that would support their domestication process based on growth performance and survival rate in controlled media. The catfish's total length and body weight were measured every two weeks within the 56 days of rearing. The experiment was conducted with a completely randomized design composed of three treatment groups (based on fish length size) and four replications, namely 3.5-4.0 cm (group A), 4.9-5.6 cm (group B), and 7.0-8.0 cm (group C) with a density of five fish per pond. Results indicated that the catfish could live in a saline water pond. The growth performance of treatment group B was higher than treatment group A and $\mathrm{C}$ with absolute length growth $(L m)$ values of $2.19 \pm 0.63 \mathrm{~cm}$, the daily growth rate in length $(D G R L)$ of $0.04 \pm 0.05$ $\mathrm{cm} /$ day, relative growth rate (RGR) of $0.51 \pm 0.58 \% /$ day, and specific growth rate of $(S G R) 1.63 \pm 0.74 \% /$ day. However, the highest

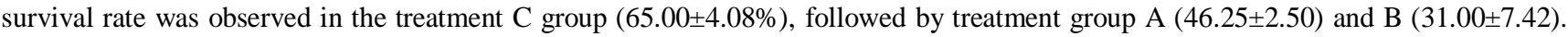
These findings will assist in the domestication of striped eel catfish to support the conservation of striped catfish populations in the future.
\end{abstract}

Keywords: Domestication, growth, Plotosidae, Plotosus lineatus, restocking

\section{INTRODUCTION}

Diversification of seafood is crucial to help fulfill demands, especially in the attempt to alleviate dependency and stress on intensive marine fisheries. The striped eel catfish, Plotosus lineatus (Thunberg 1787), well known as "lele laut", which can be found in Indonesian waters, is a consumable species that can help expand fish-based food variety (Asriyana and Halili 2021a). Fish is important in ensuring food security, especially among the poorest people in this country (Aboagye et al. 2020). Striped eel catfish have similar characteristics with a tail the freshwater catfish (Clarias batrachus), with its strong prickly front dorsal and pectoral fins, four pairs of barbels, elongated body, and brown skin with two white lines passing through the fish head (White et al. 2013). Besides possessing a high amount of amino acid, striped eel catfish also contains carbohydrates, protein, and lipid. Some fatty acids, such as monounsaturated fatty acid (MUFA); polyunsaturated fatty acid (PUFA), are contained in their fish oil (Asriyana et al. 2020a). Because of its high nutritional value for humans, sustainable management of this species is required to avoid the depletion of stocks in nature as occurs in other species (Asriyana et al. 2018; Asriyana and Halili 2021b). This sustainability can be achieved through fish domestication. In fisheries, domestication is an effort to culture fishes that live (uncontrolled) in the wild to control their growth and reproduction in rearing pond conditions.

Striped eel catfish is one of the wild marine fishes which has not been domesticated yet. Alternatively, the grey eel catfish, Plotosus canius (Hamilton 1822), has been domesticated in some countries such as India (Mijkherjee et al. 2002) and Thailand (Amornsakun et al. 2018). Domestication is generally defined as a process for controlling the raising, care, and feeding of an animal under human supervision (Zeder 2012). Domestication is intended to promote the continuous availability of animal protein to fulfill demands.

Before domestication, the growth and survival of the fish to be domesticated should be thoroughly investigated. Prior researches have studied the growth of striped eel catfish in the wild (Vijayakumaran 1997; Farooq et al. 2017; Palla et al. 2018; Asriyana et al. 2020a). However, studies related to its growth performance and survival rate in controlled rearing media are still limited wherefore this experiment is a preliminary study for this fish species. The present study especially considers the significance of information on the growth performance and survival rate of the striped catfish in its acclimation to domestication. This study aims to analyze the growth performance and survival rate of striped eel catfish that are reared in a controlled condition and determine the optimum size for growing the fish. 


\section{MATERIALS AND METHOD}

\section{Juvenile collection and stocking}

Striped eel catfish juveniles used in this experiment were caught from Tanjung Tiram waters, Southeast Sulawesi, Indonesia (Figure 1). Fish juveniles were caught when the sea was the tide move by using the fishnet with a size of $2.88 \mathrm{~cm}$ in length and $1.20 \mathrm{~cm}$ in width where the mesh size was about $0.5 \mathrm{~cm}$ in size. All juveniles caught were then placed in a reservation pond to acclimatize before being distributed into experiment pond media.

\section{Experimental design}

Fish rearing was performed for 56 days (June to August 2021) at the Field Laboratory of the Faculty of Fisheries and Marine Science, Halu Oleo University. The fish sizes used in this experiment varied in length size, between 3.5$8.0 \mathrm{~cm}$. Sixty fish juveniles were distributed into twelve concrete ponds (five fish per pond) with a pond size of 45 $\mathrm{cm}$ in diameter and $40 \mathrm{~cm}$ in height with the water-filled to $30 \mathrm{~cm}$ (Figure 2). The fish density of five fish per pond was selected with no specific reasoning as there was no prior information available on the precise density for this wild species to be reared in the pond.

The experiment was conducted by using a completely randomized design with three treatment groups and four replications. Treatment groups were based on the length size of the fish: length size of 3.5-4.0 cm (treatment group A), length size of 4.9-5.6 cm (treatment group B), or length size of 7.0-8.0 cm (treatment group C).

The fish was fed with trash fish two times a day (08.00 a.m and 04.00 p.m) at $10 \%$ quantity of the body weight. Trash fish comes from pieces of anchovy (Stolephorus commersonnii) which are finely chopped to fit the size of the catfish's mouth opening. Measurements of the total length and body weight were conducted every 14 days. The fish length was measured by a ruler with a precision of 1 $\mathrm{mm}$, while the body weight was measured using a balance with $0.01 \mathrm{~g}$ precision.

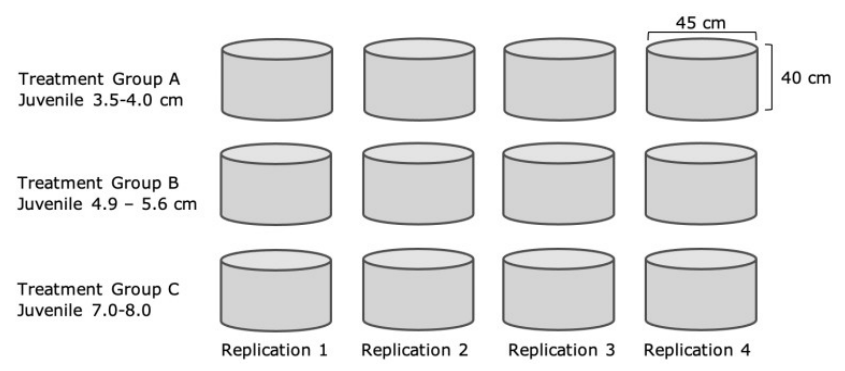

Figure 2. Experimental design of rearing media of striped eel catfish
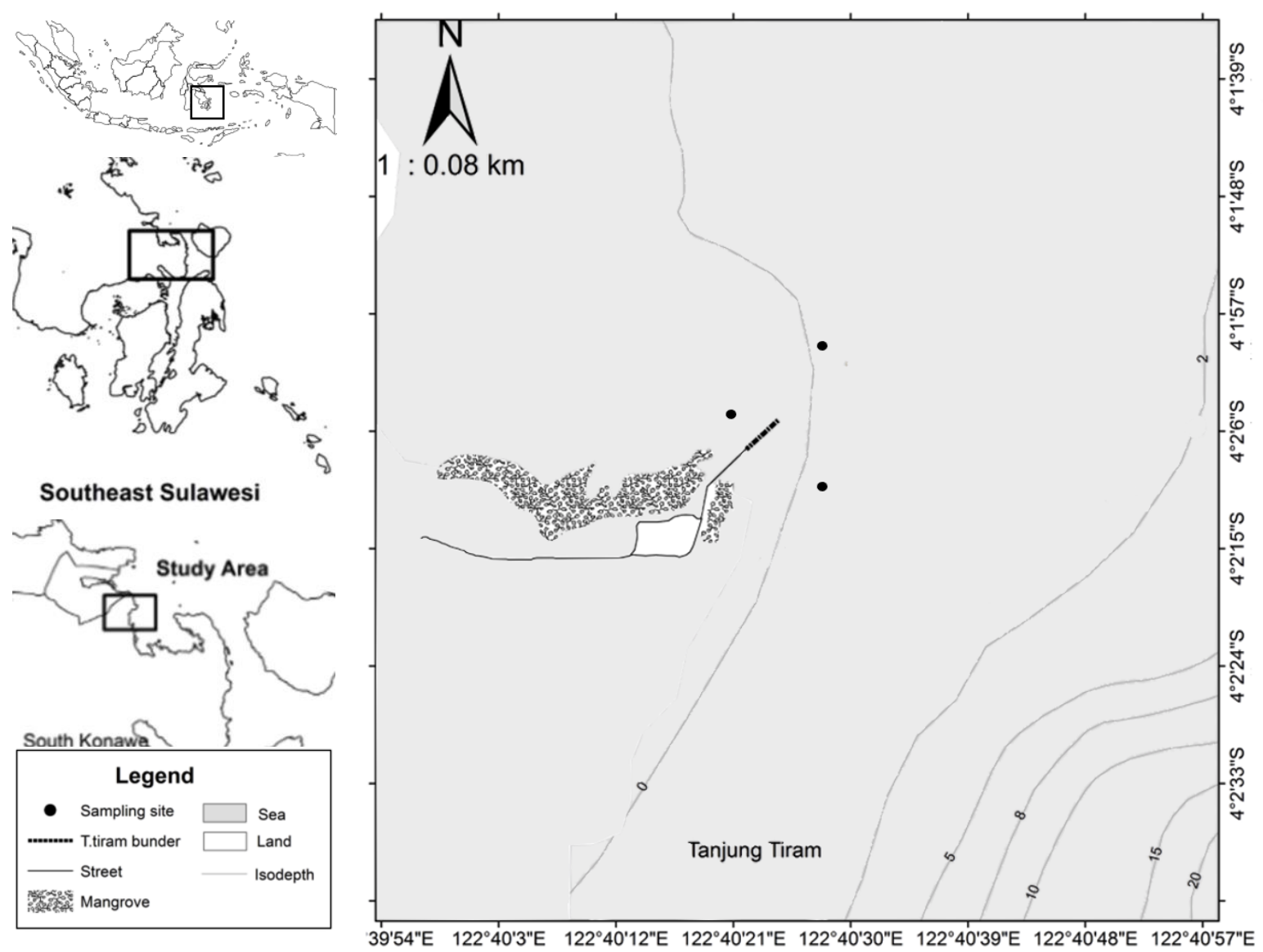

Figure 1. Map of Tanjung Tiram coast and locations of sampling stations in Southeast Sulawesi, Indonesia (Modification of Asriyana et al. 2020b) 


\section{Water quality management}

During the rearing of juvenile catfish, water quality was managed through a controlled recirculation system and water changes in the recirculation system were carried out every three days. Water quality parameters such as temperature, $\mathrm{pH}$, salinity, and dissolved oxygen were measured every fourteen days concurrently with the measurement of fish length and weight gain. Water temperature and $\mathrm{pH}$ were measured with a mercury thermometer and $\mathrm{pH}$ meter (Hanna HI-98128), respectively. The water salinity was measured by using a handheld refractometer (Atago 2382), while dissolved oxygen was measured with a DO meter (Lutron DO-5510).

During the rearing of juvenile catfish, water quality was managed through a controlled recirculation system, and water changes in the recirculation system were carried out every three days.

\section{Calculations and statistical analysis}

All data collected were then analyzed to determine the total length and daily length growth (Jobling 2003), relative growth rate (De Silva and Anderson 1995), specific growth rate (Limbu 2020), and survival rate (Aryani et al. 2017; Limbu 2020).

The total length of the catfish was calculated with the formula from Jobling (2003):

$$
L_{m}=L_{t}-L_{0}
$$

Where, Lm: Total length of catfish $(\mathrm{cm})$; $\mathrm{L}_{\mathrm{t}}$ : Average total length at the end of rearing $(\mathrm{cm}) ; \mathrm{L}_{0}$ : Average initial total length $(\mathrm{cm})$.

Meanwhile, the daily length growth rate was determined using the following formula (Jobling 2003):

$$
D G R_{L}=\frac{L_{L}-L_{n}}{t}
$$

Where, DGRL: Daily length growth rate (cm/day); Lt: Final body length $(\mathrm{cm})$; Lo: Initial body length $(\mathrm{cm})$; t: Rearing time (days).

The relative growth rate was analyzed by using the formula from De Silva dan Anderson (1995):

$$
R G R=\frac{W_{L}-W_{0}}{W_{0} x t} \times 100 \%
$$

Where, RGR: Relative growth rate (\%/day); $\mathrm{W}_{\mathrm{t}}$ : Average final body weight $(\mathrm{g}) ; \mathrm{W}_{0}$ : Average initial body weight (g); t: Rearing time (days).

The specific growth rate was determined using the formula from Limbu (2020):

$$
S G R=\frac{\operatorname{Ln} W_{\mathrm{L}}-\operatorname{Ln} W_{0}}{t} \times 100 \%
$$

Where, SGR: Specific growth rate (\%/day); Wt: Final Body weight (g); Wo: Initial body weight (g); t: Rearing time (days).

The survival rate was analyzed by using the combined formulae from Aryani et al. (2017) and Limbu (2020):

$$
S R=\frac{\mathbb{N}_{\mathrm{E}}}{\mathrm{N}_{0}} x 100 \%
$$

Where, SR: Survival rate (\%); $\mathrm{N}_{\mathrm{t}}$ : Final total amount of fish (individual); $\mathrm{N}_{\mathrm{o}}$ : Initial total amount of fish (individual).

To determine whether there were differences in the growth performance and survival rates values among the treatment, non-parametric statistic Kruskal-Wallis with significant 0.05 (Sokal and Rohl 1995) was used using SPSS ver. 28.0 (IBM SPSS Statistic).

\section{RESULTS AND DISCUSSION}

\section{Water quality}

Water quality parameters throughout the fish rearing period are shown in Table 1. Water temperature, $\mathrm{pH}$, salinity, and dissolved oxygen of the rearing media have relatively small differences between treatment groups.

\section{Growth performance}

The striped eel catfish juvenile reared in the concrete ponds for 56 days showed good growth both in the length and weight gains for all treatments (Figure 3). Body length growths in groups $\mathrm{A}, \mathrm{B}$, and $\mathrm{C}$ were ranged between $3.97 \pm 0.11-4.94 \pm 0.11 \mathrm{~cm} ; 5.10 \pm 0.18-7.29 \pm 0.20 \mathrm{~cm}$; and $7.49 \pm 0.36-9.55 \pm 0.69 \mathrm{~cm}$, respectively. Whereas, the weight gains of the fish in groups $\mathrm{A}, \mathrm{B}$, and $\mathrm{C}$ were ranged between $1.04 \pm 0.32-1.09 \pm 0.21 \mathrm{~g} ; 1.00 \pm 0.38-2.48 \pm 0.28 \mathrm{~g}$; and $2.30 \pm 0.43-5.01 \pm 0.77 \mathrm{~g}$, respectively.
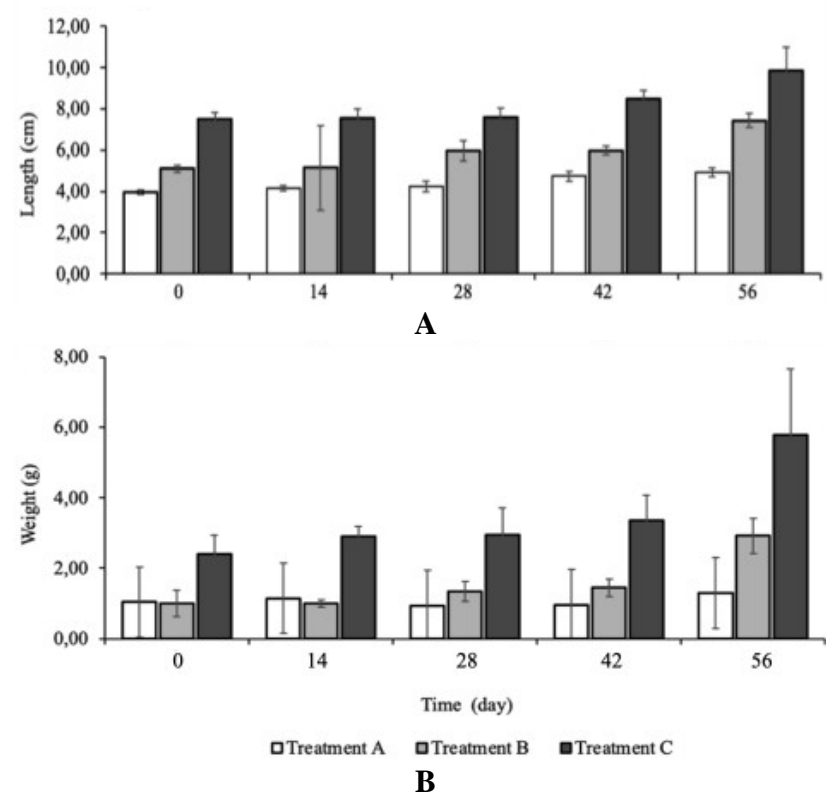

Figure 3. Growth of the striped eel catfish during the rearing period. A. Fish length; B. Fish weight, I: Standar deviation 
Table 1. Water quality parameters of rearing media of striped eel catfish

\begin{tabular}{ccccc}
\hline Treatments & Temperature $\left({ }^{\circ} \mathbf{C}\right)$ & $\mathbf{p H}$ & Salinity (\%o) & Dissolved Oxygen $(\mathbf{m g} / \mathbf{L})$ \\
\hline A & $27.00 \pm 0.00$ & $7.82 \pm 0.92$ & $31.10 \pm 1.25$ & $4.98 \pm 0.13$ \\
B & $27.10 \pm 0.97$ & $7.59 \pm 0.86$ & $30.70 \pm 1.08$ & $4.95 \pm 0.11$ \\
C & $27.48 \pm 1.19$ & $7.34 \pm 0.85$ & $30.80 \pm 0.70$ & $5.04 \pm 0.16$ \\
\hline
\end{tabular}

Note: $p>0.05$ ( $\alpha: 5 \%$, df: 2$)$, the Kruskall Wallis Test

Table 2. Average fish length and fish length increase during the rearing period

\begin{tabular}{cccccccc}
\hline \multirow{2}{*}{ Day } & \multicolumn{2}{c}{ Group A } & & Group B & \multicolumn{2}{c}{ Group C } \\
\cline { 2 - 7 } & $\bar{L}$ & $\Delta \bar{L}$ & $\bar{L}$ & $\Delta \bar{L}$ & $\bar{L}$ & - \\
14 & 3.97 & - & 5.10 & - & 0.03 & 79 & 0.06 \\
28 & 4.16 & 0.19 & 5.13 & 0.83 & 7.60 & 0.05 \\
42 & 4.23 & 0.08 & 5.96 & 0.02 & 8.48 & 0.88 \\
56 & 4.73 & 0.50 & 5.98 & 1.31 & 9.55 & 1.07 \\
\hline
\end{tabular}

Note: $\bar{L}=$ mean length; $\Delta \bar{L}=$ length increase

Table 3. Weight gain and weight gain increase of the stripped eel catfish during the rearing period

\begin{tabular}{|c|c|c|c|c|c|c|}
\hline \multirow{2}{*}{ Day } & \multicolumn{2}{|c|}{ Treatment A } & \multicolumn{2}{|c|}{ Treatment B } & \multicolumn{2}{|c|}{ Treatment C } \\
\hline & $\bar{W}$ & $\Delta \bar{W}$ & $\bar{W}$ & $\Delta \bar{W}$ & $\bar{W}$ & $\Delta \bar{W}$ \\
\hline 0 & 1.04 & & 1.00 & & 2.30 & \\
\hline 14 & 1.14 & 0.10 & 1.00 & 0.00 & 2.69 & 0.38 \\
\hline 28 & 0.93 & -0.21 & 1.34 & 0.34 & 2.94 & 0.25 \\
\hline 42 & 0.96 & 0.02 & 1.45 & 0.10 & 3.37 & 0.43 \\
\hline 56 & 1.09 & 0.13 & 2.48 & 1.04 & 5.01 & 1.64 \\
\hline
\end{tabular}

Note: $\bar{W}=$ mean weight; $\Delta \bar{W}=$ weight gain increase

Table 4. Growth performances of striped eel catfish in different treatment groups

\begin{tabular}{ccccc}
\hline $\begin{array}{c}\text { Treatment } \\
\text { Group }\end{array}$ & $\begin{array}{c}L_{m} \\
(\mathbf{c m})\end{array}$ & $\begin{array}{c}\text { x0001_ } \\
(\mathbf{c m} / \mathbf{d a y})\end{array}$ & $\begin{array}{c}\boldsymbol{R} \boldsymbol{G R} \\
(\boldsymbol{\%} / \mathbf{d a y})\end{array}$ & $\begin{array}{c}\boldsymbol{S G R} \\
(\% / d a y)\end{array}$ \\
\hline A & $0.98 \pm 0.18$ & $0.02 \pm 0.01$ & $0.04 \pm 0.26$ & $0.09 \pm 1.07$ \\
B & $2.19 \pm 0.63$ & $0.04 \pm 0.05$ & $0.51 \pm 0.58$ & $1.63 \pm 1.74$ \\
C & $2.07 \pm 0.54$ & $0.04 \pm 0.04$ & $0.41 \pm 0.34$ & $1.41 \pm 1.03$ \\
\hline$p<0.05$ (a: $5 \%$, df: 2$)$, the Kruskal-Wallis Test; $L_{m}:$ absolute \\
length growth; $D G R_{L}:$ day growth rate in length; $R G R:$ relative \\
growth rate; $S G R:$ specific growth rate
\end{tabular}

The growth in fish length and weight were found to be varied between treatment groups. The lowest fish length growth was observed in treatment A $(0.24 \mathrm{~cm})$ (Table 2$)$, whilst the highest fish length growth was found in treatment B $(0.55 \mathrm{~cm})$. Similarly to the fish length, the weight gain also varied between treatment groups. The weight gain in group A decreased on the 28th day (-0.21 g), and increased again on the 42nd day and 56th day (Table 3 ). Meanwhile, the fish weight gains in treatment groups B and $\mathrm{C}$ showed continuous growth with the weight gains between the two different. The change in weight gain in treatment group A was lowest $(0.01 \mathrm{~g})$ relative to the other two treatments, whilst the highest of weight gain was found in treatment group $\mathrm{C}(0.68 \mathrm{~g})$.

Growth data of the striped eel catfish are shown in Table 4. The striped eel catfish juveniles in treatment group $\mathrm{B}$ had the highest length gain, daily length growth, relative growth rate, and specific growth rate. Contrastingly, the fish juveniles in treatment group A showed the poorest growth performance between the three groups. This condition can also be seen from the results of the Kruskall Wallis test, where there are significant differences between treatments for growth performance $(p<0.05$, a: $5 \%$, df: 2$)$.

\section{Survival rate}

The survival rates of the striped eel catfish during the experiment are shown in Figure 4. The highest SR was found in treatment group $\mathrm{C}(65.00 \pm 4.08 \%)$ in comparison to treatment groups A $(31.00 \pm 7.42 \%)$ and B $(46.25 \pm 2.50 \%)$. Kruskall Wallis results showed that significant differences in SR can be identified between the treatments ( $p$ : $0.007 ; p<0.05$, a: $5 \%$, df: 2 ).

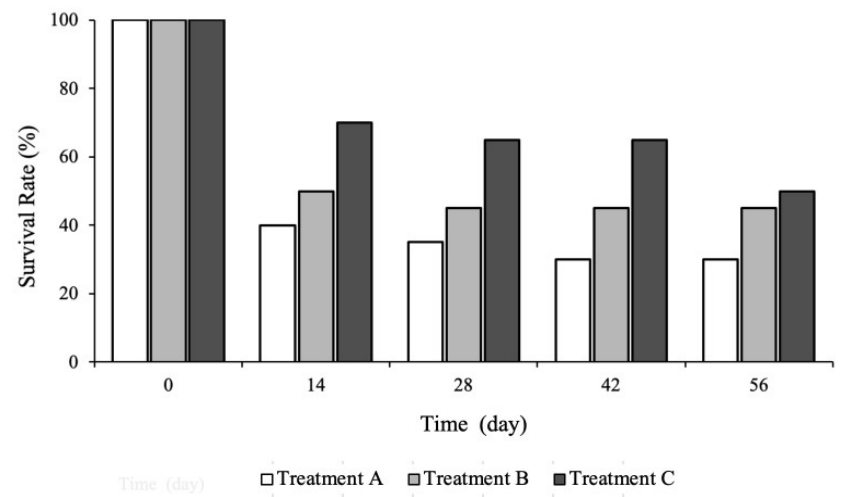

Figure 4. Survival rates of striped eel catfish juveniles during the rearing period 


\section{Discussion}

Fish growth is defined as the increased change process of fish size either in terms of length or weight within a particular time. The striped eel catfish juveniles showed considerable growth after 56 days of the rearing period. Treatment group A (fish length size: $3.5-4.0 \mathrm{~cm}$ ) had the lowest increase in length gains than treatment B and C. Moreover, the catfish in treatment group B $(4.9-5.6 \mathrm{~cm})$ showed the biggest rate of increase in fish length if compared with treatment groups $\mathrm{A}$ and $\mathrm{C}$. Change in an increase in length can also be viewed as the length growth rate of the juveniles in all treatments (Table 2). On the 28th day, the growth of the fish in treatment groups A and C increased only $0.08 \mathrm{~cm}$ and $0.05 \mathrm{~cm}$, respectively. While the fish growth in treatment B showed a higher growth of $0.83 \mathrm{~cm}$. Despite the decrease in growth rate in the treatment groups $\mathrm{A}$ and $\mathrm{C}$ on day 42, their growth on the 56th day had significantly increased to $1.31 \mathrm{~cm}$ in length change. A similar pattern of increase can also be observed in the daily length growth of the fish (Table 4). The daily length growth of the juveniles in treatment group B was highest among the treatment groups $(0.04 \pm 0.05 \mathrm{~cm} /$ day $)$ The results were different from the data on the striped eel catfish living in the wild. Comparatively, they are generally smaller in size with faster growth in comparison to the big size fish. Bigger fish size commonly infers smaller length growth following the von Bertalanffy curve (Vijayakumaran 1997; Asriyana et al. 2020a). The findings are similar to that reported for orange-spotted spine foot (Siganus guttatus) in aquaculture, in which smaller-sized fish (3.00-3.50 cm) had higher daily length growth than bigger-sized fish $(4.10-5.00 \mathrm{~cm})$ (Lante et al. 2011). The difference in length growth rate between the two fishes under controlled conditions was suspected because of the inadequate adaption to the environment within control media, prompting the striped eel catfish to be stressed and this affected their growth.

The specific growth rate in the fish size of $4.9-5.6 \mathrm{~cm}$ showed the highest value $(1.63 \pm 1.74 \%$ /day $)$ than the fish sizes of $3.00-3.50 \mathrm{~cm}$ and $7.0-8.0 \mathrm{~cm}$. A similar trend of results was shown in the relative growth rate (Table 4). To put into perspective, the African catfish (Clarias gariepinus) has a fish length of $3 \mathrm{~cm}$ and an SGR of $0.97 \pm 0.07 \% /$ day (Dewi et al. 2013). This species, by comparison, has higher values of the two parameters than the striped eel catfish, which has an SGR of $0.09 \pm 1.07 \% /$ day. Furthermore, the SGR of the striped eel catfish of 7.0-8.0 $\mathrm{cm}$ size was found to be higher than the striped catfish (Pangasius hypophthalmus) with a length of $7.0-8.0 \mathrm{~cm}$ and growth rate of $0.037 \pm 0.0013 \% /$ day (Andriani et al. 2019).

In a similar fish length size, the SGR of African catfish is higher than the SGR of striped eel catfish because the African catfish juveniles were produced from artificial spawning. Moreover, the catfish also has a uniform size and could better adapt to the controlled rearing media. Contrarily, the striped eel catfish juveniles were acquired from the wild and had a very short adaptation period of one week before treatments. This condition caused storable energy in the body to be less. In addition, the disrupted physiology of the fish would also discourage the fish from consuming feed, thus leading to decreased energy supply that could be used and stored in the body. As the energy used for the adaptation process was larger than normal, the energy to be used for growth was, as a result, less, causing a decrease or lower weight or rate of weight gain of the fish. The low SGR value of the striped catfish ( $P$. hypophthalmus) of the same size in this study might be caused by the high density of fish distribution in the pond (200 ind./pond). In contrast, the fish density in this treatment was only 5 ind./pot. The high density would cause competition for food and space between the fish. Furthermore, high density would imply high feces production that harms the water quality of the fish rearing media. High fish density was not able to provide adequate feed for tropical gar (Atractosteus tropicus) juveniles (Martínez-Cárdenas et al. 2020).

SGR is the daily growth rate or increase in the percentage of fish weight within one day. An increase in growth can be identified through the increase in RGR and SGR values. The values obtained for the two aspects showed that the striped eel catfish juveniles in treatment group B could digest and absorb considerable nutrients and store them inside the body to be converted into energy. This stored energy, then, would be utilized by the fish for growth (gains in length and weight) with the lesser needed energy for basal metabolism, moving, and maintenance of the fish body.

Survival rate (SR) is a parameter that can help denote whether a fish culture can be successfully conducted or not. During the rearing period, water quality parameters were not significantly different between treatment groups ( $p>0.05$, a: $5 \%$, df: 2 , Table 1). The water recirculation system had succeeded in controlling the water quality of the fish rearing. This is most important so as wild fish are generally very sensitive to changes in water condition of rearing media (Jumaidi et al. 2016). Furthermore, fish juveniles require an optimum environment for their growth (Enache et al. 2011). The low SR of the fish (SR: 40-70\%) in the initial rearing period might be caused by the fact that the fish were still adapting to the water conditions of the rearing media even past the acclimatization period as set in the experiment (Figure 4). The low SR of the fish could also be attributed to column or space competition as well as feed residue and metabolic waste deposited, which can be toxic.

As the striped eel catfish had not yet been domesticated previously, references on the optimum density for this were not yet available species. Though, the schooling behavior of a fish during their juvenile stage (Taylor and Gomon 1986) can be used as a reference for an experiment. However, because of the limited space of rearing media available, the movements of the striped eel catfish juveniles were significantly constricted. Some fish found dead were observed to experience injury on parts of their head. It was indicated that the catfish had experienced a collision with the wall of the pond as the fish had moved so fast. Frequencies of this eventually led some fish to die. This occurred within the experiment signifies that larger rearing means are needed for the fish. 
Unconsumed feed (residue) and metabolism waste that had accumulated at the bottom of the media were most likely decomposed by bacteria (aerobic or anaerobic) to, generally, produce phosphate and nitrogen. From the total amount of feed consumed, the fish could only absorb 20$30 \%$, the rest were excreted as ammonia and organic protein as end products of the protein metabolic process (Avnimelech 2006). Additionally, of the $80 \%$ nitrogen component from the secretion, $90 \%$ is ammonia and $10 \%$ is uric acid (Ebeling et al. 2006). Ammonia is toxic for aquatic organisms as it reduces dissolved oxygen and generates unwanted changes in the aquatic ecosystem (Elbialy et al. 2021). Ammonia is especially toxic for fish culture at a concentration of $>1.5 \mathrm{mg} \mathrm{N} / 1$. In some cases, some aquatic organisms are only able to tolerate ammonia as much as $0.025 \mathrm{mg} \mathrm{N} / 1$ (Chen et al. 2006; Cheng et al. 2015; Wahyuningsih and Gitarama 2020). Cultured fishes have varying tolerance towards ammonia - nitrogen depending on their species, age, and physiology (Romano and Zeng 2013). Fishes that live in warm waters can tolerate ammonia than fishes that live in cold waters, while mature fish are more tolerant than juveniles (Dauda et al. 2019). Excessive ammonia exposure can cause ammonia excretion to be disturbed. It will increase ammonia absorption and promote fish fatality (Sinha et al. 2012). The present study had not accounted for ammonia in water, i.e., ammonia content could have been a plausible factor in the death of fish but was not measured in the experiment. Thus, in the following studies, the ammonia level should be measured periodically to help predict how SR can be managed with ammonia content. Aside from SR being influenced by water quality, SR is also affected by age, fish behavior, feed, and fish health condition as reported by Adewolu et al. 2008 on African catfish (C. gariepinus); and Robisalmi et al. 2017 on blue tilapia (Oreochromis aureus). Blue tilapia juveniles that had higher body weight had higher SR than those that had smaller body weight.

The fish juveniles in treatment group C $(7.0-8.0 \mathrm{~cm})$, which had the biggest size, had the highest survival rate $(65.00 \pm 4.08 \%)$ compared to the juveniles in treatment groups B and A with values of 3.00-3.50 cm and 4.9-5.6 $\mathrm{cm}$, respectively. Different from the striped eel catfish, African catfish in size of $3 \mathrm{~cm}$ showed SR of $53.3 \pm 1.76$ (Dewi et al. 2013); higher than the SR of striped eel catfish with the size of $3.00-3.50 \mathrm{~cm}$. Higher SR in bigger sized fish was also reported by Hutchings (1994) in brook trout (Salvelinus fontinalis); Bradford (1995) in Pacific salmon (Oncorhynchus spp.); Robisalmi et al. (2017) in blue tilapia juvenile; and Andriani et al. (2019) in striped catfish $(P$. hypophthalmus). Hutchings (1994) reported that the survival rate of fish brook trout had a positive correlation with fish body size. While in Pacific salmon, the survival rate increases according to fish age. Survival rate values approaching $100 \%$ are closely related to the good water environment and quality as well as contained biomass and ideal fish density (Ronald et al. 2014; Martínez-Cárdenas et al. 2020). In blue tilapia, it was shown that bigger-sized juveniles tended to have better body conditions compared to the smaller-sized juveniles (Robisalmi et al. 2017).
Results showed that striped eel catfish juveniles could be domesticated in controlled media. To culture the fish, juveniles with a size of $4.9-5.6 \mathrm{~cm}$ seemed to be most ideal in terms of RGR and SGR $(0.51 \pm 0.58 \%$ day and $1.63 \pm 1.74 \% /$ day, respectively) compared to the other fish sizes. However, in terms of restocking, the biggest fish juvenile size of 7.0-8.0 $\mathrm{cm}$ observed in this experiment is most recommended as it had the highest SR $(65.00 \pm 4.08 \%)$ among all the fish sizes. The findings of the present study were still limited because no prior studies are available as references to help determine optimum fish density and feed amount, and had proven to be a considerable challenge to be considered for following studies on the culture of striped eel catfish.

\section{ACKNOWLEDGEMENTS}

The authors are grateful to Risko Arsyad, S.Pi. and undergraduate students of the Faculty of Fisheries and Marine Sciences of Halu Oleo University (Raudhatul Madhaniah; Murni Astuti; Heriandi; and Dicky Ardiansyah) for their assistance in collecting data in the area; Faculty of Fisheries and Marine Sciences, Halu Oleo University for all the support of the facilities in completing this research. This research was supported by Kementerian Pendidikan, Kebudayaan, Riset, dan Teknologi Republik Indonesia (Grant number: 026/E4.1/AK.04.PT/2021) with the title "Sustainable management design of eel catfish fishery (Plotosus sp.) towards food resilience in Southeast Sulawesi".

\section{REFERENCES}

Aboagye E, Tano-Debrah K, Kunadu AP. 2020. Microbial quality of fish along with the Tilapia, African catfish and Sardinella artisanal value chains in Kpong and James Town, Ghana. Bonorowo Wetlands 10 (1): 1-17. DOI: 10.13057/bonorowo/w100101.

Adewolu MA, Adenji CA, Adejobi AB. 2008. Feed utilization, growth and survival of Clarias gariepinus (Burchell 1882) fingerlings cultured under different photoperiods. Aquaculture 283: 64-67. DOI: 10.1016/j.aquaculture.2008.07.020.

Amornsakun T, Krisornpornsan B, Jirasatian P, Pholrat T, Pau TM, bin Hassan A. 2018. Some reproductive biological aspects of gray-eel catfish, Plotosus canius Hamilton, 1822 spawner in Pattani Bay, Thailand. Songklanakarin J Sci Technol 40 (2): 384-389. DOI: 10.14456/sjst-psu.2018.59.

Andriani Y, Zahidah, Dhahiyat Y, Hamdani H, Subhan U. 2019. Growth of juvenile striped catfish (Pangasius hypophthalmus) and water quality in aquaponics system. Asian J Fish Aquat Res 5 (2): 1-7. DOI: 10.9734/ajfar/2019/v5i230071.

Aryani N, Azrita, Mardiah A, Syandri H. 2017. Influence of feeding rate on the growth, feed efficiency and carcass composition of the giant gourami (Osphronemus goramy). Pak J Zool 49 (5): 1775-1781. DOI: 10.17582/journal.pjz/2017.49.5.1775.1781.

Asriyana, Irawati N, Indrayani. 2018. Trophic ecology of twoblotch ponyfish Nuchequula blochii in Kendari Bay, Southeast Sulawesi, Indonesia. AACL Bioflux 11 (1): 66-82.

Asriyana A, Halili H, Irawati N. 2020a. Size structure and growth parameters of striped eel catfish (Plotosus lineatus) in Kolono Bay, Southeast Sulawesi, Indonesia. AACL Bioflux 13 (1): 268-279.

Asriyana A, Irawati N, Halili H. 2020b. Length-weight relationships and ponderal index of three reef fish (Teleostei: Labridae) off the Tanjung Tiram coast, Southeast Sulawesi, Indonesia. Biodiversitas 21 (4): 1279-1286. DOI: 10.13057/biodiv/d210402. 
Asriyana A, Halili H. 2021a. Reproductive traits and spawning activity of striped eel catfish (Plotosidae) in Kolono Bay, Indonesia. Biodiversitas 22 (7): 3020-3028. DOI: 10.13057/biodiv/d220756.

Asriyana A, Halili H. 2021b. Diversity of Mullidae as by-catch of Plotosidae fishery in the waters of Southeast Sulawesi, Indonesia. AACL Bioflux 14 (2): 621-634.

Avnimelech Y. 2006. Bio-filters: The need for an new comprehensive approach. Aquac Eng 34: 172-178. DOI 10.1016/j.aquaeng.2005.04.001.

Bradford MJ. 1995. Comparative review of Pacific salmon survival rates Can J Fish Aquat Sci 52: 1327-1338. DOI: 10.1139/f95-129.

Chen S, Ling J, Blancheton JP. 2006. Nitrification kinetics of biofilm as affected by water quality factors. Aquac Eng 34: 179-197. DOI: 10.1016/j.aquaeng.2005.09.004.

Cheng CH, Yang FF, Ling RZ, Liao SA, Miao YT, Ye CX, Wang AL. 2015. Effects of ammonia exposure on apoptosis, oxidative stress and immune response in pufferfish (Takifugu obscurus). Aquat Toxicol 164: 61-71. DOI: 10.1016/j.aquatox.2015.04.004.

Dauda AB, Ajadi A, Tola-Fabunmi AS, Akinwole AO. 2019. Waste production in aquaculture: Sources, components and managements in different culture systems. Aquac Fish 4 (3): 81-88. DOI: 10.1016/j.aaf.2018.10.002.

De Silva SS, Anderson TA. 1995. Fish Nutrition in Aquaculture Chapman and Hall, 2-6 Boundary Row, London.

Dewi CD, Muchlisin ZA, Sugito. 2013. Growth performance and survival rate of African catfish larvae (Clarias gariepinus) at different concentration of jaloh leaf powders (Salix tetrasperma Roxb) in the formulated diet. Depik 2 (2): 45-49. DOI: 10.13170/depik.2.2.725. [Indonesia].

Ebeling JM, Timmons M, Bisogni JJ. 2006. Engineering analysis of the stoichiometry of photoautotrophic, autotrophic, and heterotrophic removal of ammonia-nitrogen in aquaculture systems. Aquaculture 257 (1-4): 346-358. DOI: 10.1016/j.aquaculture.2006.03.019.

Elbialy ZI, Salah AS, Elsheshtawy A, Rizk M, Abualreesh MH, AbdelDaim MH, Salem SMR, Askary AE Assar DH. 2021. Exploring the multimodal role of yucca schidigera extract in protection against chronic ammonia exposure targeting: Growth, metabolic, stress and inflammatory responses in nile tilapia (Oreochromis niloticus L.). Animals 11 (7): 1-20. DOI: 10.3390/ani11072072.

Enache I, Cristea V, Ionescu T, Ion S. 2011 The influence of stocking density on the growth of common carp, Cyprinus carpio, in a recirculating aquaculture system. AACL Bioflux 4 (2): 146-153.

Farooq N, Qamar N, Rashid S, Panhwar SK. 2017. Length-weight relationship of eleven species of marine catfishes from the northern Arabian Sea coast of Pakistan. Chin J Oceanol Limnol 35 (5): 1218 1220. DOI: $10.1007 / \mathrm{s} 00343-017-6117-2$.

Hutchings JA. 1994. Age- and size-specific costs of reproduction within and among populations of brook trout, Salvelinus fontinalis. Oikos 70 (1): 12-20. DOI: $10.2307 / 3545693$.

Jobling M. 2003. The thermal growth coefficient (TGC) model of fish growth: A cautionary note. Aquac Res 34: 581-584. DOI: 10.1046/j.1365-2109.2003.00859.x.

Jumaidi, Ahmad, Yualianto H, Effendi E. 2016. Effect of stocking density on feed utilization efficiency, growth and survival of java barb (Puntius javanicus) in a recirculation system. E-Jurnal Rekayasa dan Teknologi Budidaya Perairan 5 (1): 587-596. [Indonesia]
Lante S, Adhiyudanto NB, Palinggi NN. 2011. Nursery of orange-spotted spinefoot (Siganus guttatus) with different juvenile body sizes. Proceedings of Aquaculture Technology Innovation Forum. pp 419423.

Limbu SM. 2020. The effects of on-farm produced feeds on growth, survival, yield and feedcost of juvenile African sharptooth catfish (Clarias gariepinus). Aquac Fish 5 (1): 58-64. DOI: 10.1016/j.aaf.2019.07.002.

Martínez-cárdenas L, Hernández-cortez MI, Espinosa-chaurand D, Castañeda-chavez MR, León-fernández AE, Hernández EFV, Rodríguez CEB, Álvarez-gonzález CA. 2020. Effect of stocking density on growth, survival and condition factor in tropical gar (Atractosteus tropicus Gill, 1863) juveniles. Lat Am J Aquat Res 48 (4): 570-577. DOI: 10.3856/vol48-issue4-fulltext-2452.

Mijkherjee M, Praharaj A, Das S. 2002. Conservation of endangered fish stocks through artificial propagation and larval rearing technique in West Bengal, India. Aquac Asia 7 (2): 8-11.

Palla HP, Pagliawan HB, Rodriguez EF, Cacho BSMGT, Gonzales BJ, Bonnell C, Fowler T. 2018. Length-weight relationship of marine fishes from Palawan, Philippines. The Palawan Scientist 10: 17-28

Robisalmi A, Setyawan P, Gunadi B. 2017. Effect of different male and female sex ratio on growth of juvenile blue tilapia, Oreochromis aureus (Steindachner 1864). Jurnal Iktiologi Indonesia 17 (1): 55-65. DOI: 10.32491/jii.v17i1.304. [Indonesia]

Romano N, Zeng C. 2013. Toxic effects of ammonia, nitrite, and nitrate to decapod crustaceans: A review on factors influencing their toxicity, physiological consequences, and coping mechanisms. Rev Fish Sci 21 (1): 1-21. DOI: $10.1080 / 10641262.2012 .753404$

Ronald N, Gladys B, Gasper E. 2014. The effects of stocking density on the growth and survival of nile tilapia (Oreochromis niloticus) fry at son fish Farm, Uganda. J Aquac Res Dev 5 (2): 1-7. DOI: 10.4172/2155-9546.1000222.

Sinha AK, Liew HJ, Diricx M, Blust R, Boeck GD. 2012. The interactive effects of ammonia exposure, nutritional status and exercise on metabolic and physiological responses in gold fish (Carassius auratus L.). Aquat Toxicol 109: 33-46. DOI: 10.1016/j.aquatox.2011.11.002.

Sokal RR, Rohlf FJ. 1995. Biometry: The Principles and Practice of Statistics in Biological Research. 3rd Edition. WH Freeman and Co, New York.

Taylor WR, Gomon JR. 1986. Plotosidae. In: Daget J, Gosse JP, van den Audenaerde DFET (eds). Check-list of the Freshwater Fishes of Africa (CLOFFA). ISBN, Brussels; MRAC, Tervuren; ORSTOM, Paris.

Vijayakumaran K. 1997. Growth and mortality parameters and some aspects of biology of striped eel catfish Plotosus lineatus (Thunberg) from north Andhra Pradesh coast. J Mar Biol Assoc India 39 (1-2): 108-112.

Wahyuningsih S, Gitarama AM. 2020. Ammonia system in fish cultivation. Syntax Literate: Jurnal Ilmiah Indonesia 5 (2): 112-125. DOI: 10.36418/syntax-literate.v5i2.929.

White WT, Last PR. Dharmadi, Faizah R, Chodrijah U, Prisantoso BI, Pogonoski JJ, Puckridge M, Blaber SJM. 2013. Market Fishes of Indonesia. ACIAR Monograph No. 155. Australian Centre for International Agricultural Research, Canberra.

Zeder MA. 2012. The domestication of animals. J Anthropol Res 68: 161190. DOI: 10.1080/00988157.1982.9977605. 